\title{
シートフロー漂砂量式の波・流れ交差場への拡張と 沿岸漂砂量の検討
}

\author{
Mohammad Dibajnia* • 渡 辺 晃**
}

\section{1. 序論}

現地海岸では暴浪時のみならず中規模程度の波浪条件 の下でも, 砕波帯内外を含む漂砂帯のほぼ全域でシート フロー状態の底質運動が卓越することが，これまでによ く知られている.著者らは以前に, 底面軌道流速の非対称 性ならびに定常流の共存の影響を取り込んだシートフロ 一漂砂量算定式を提案し, ネットの漂砂量の大きさと向 きを非常に精度良く予測できることを示した (Dibajnia・ Watanabe, 1992). 更にその後, この式の適用範囲を掃流 漂砂と浮遊漂砂にまで拡張するとともに，実規模実験や 実海岸における海浜の縦断地形変化をシミュレートする ための数值モデルに応用し，その妥当性を確認してきた (Dibajnia ら，1992，1993，1994)。しかしながら，この 漂砂量算定式は基本的に還流装置付き振動流水槽を用い た実験結果に基づいて導かれたものであり，振動流と定 常流とが互いに平行な順流と逆流の場合にしか適用でき ないという制約があった。

そこで本研究では，この式を更に拡張して波と流れが 任意角度で斜めに交差する場合にも適用可能な漂砂量算 定手法を提示することを目的とする. 拡張された算定法 の妥当性は, 現地海岸での底面高変化実測デー夕を用い て検証する.更に, 提示した算定法を応用することによ り, 現地スケールの様々な条件下の直線状平行等深線海 岸での斜め入射波による岸沖および沿岸漂砂量を，波・ 戻り流れ・沿岸流の共存を包含して計算する、また，計 算された総沿岸漂砂量について考察を加える.

\section{2. 漂砂量算定式の波・流れ交差場への拡張}

図一1(a) に示すように, 規則波と定常流が任意角度 で交差する単純化した条件を考える.この図で, $U$ は定 常流の流速ベクトル， $\boldsymbol{u}_{w}^{+}$と $\boldsymbol{u}_{w}^{-}$はそれぞれ波峰と波谷下 の底面近傍軌道流速べクトル, $\alpha$ は $\boldsymbol{U}$ と $\boldsymbol{u}_{w}^{+}$の交差角で ある. 定常流速ベクトル $\boldsymbol{U}$ を, 波の進行方向の成分 $\boldsymbol{U}_{w}$ と直交方向の成分 $\boldsymbol{U}_{n}$ に分解する. よって式（1）が成 立する。

* 正会員 工博 東京大学助教授 工学部土木工学科

** 正会員 工博 東京大学教授 工学部土木工学科

$$
U_{w}=U \cos \alpha, \quad U_{n}=U \sin \alpha
$$

なお,この式以降, ベクトル量 (太字体) の絶対値は細 字体で表示する.

波進行方向の底面近傍流速成分の時間波形は，周期 $T$ の軌道流速成分をuとして，一般に図一2のようになる. Dibajnia・Watanabe (1992) と同様に，正・負の流速の 継続時間を $T_{c}$ と $T_{t}$ で表し, それぞれに対応する流速の 代表値 $u_{c}^{\prime}$ と $u_{t}^{\prime}$ を次式で定義する.

$$
u_{c}^{\prime 2}=\frac{2}{T_{c}} \int_{0}^{T_{c}}\left(u+U_{w}\right)^{2} \mathrm{~d} t, \quad u_{t}^{\prime 2}=\frac{2}{T_{t}} \int_{T_{c}}^{T}\left(u+U_{w}\right)^{2} \mathrm{~d} t
$$

これにより, 時間の関数である合成流速べクトル $\boldsymbol{u}+\boldsymbol{U}_{w}$ は, 一定值をとる 2 つの流速べクトル $\boldsymbol{u}_{c}^{\prime}$ と $\boldsymbol{u}_{t}^{\prime} て ゙$ 代表さ れ，図一1(a) は図一1(b) で置き換えることができる. 更に, $\boldsymbol{u}_{c}^{\prime}$ と $\boldsymbol{U}_{n}$ のベクトル和を $\boldsymbol{u}_{c}$ で, $\boldsymbol{u}_{t}^{\prime}$ と $\boldsymbol{U}_{n}$ のベクト ル和を $\boldsymbol{u}_{t}$ で表し，もともとの流速場が最終的に継続時間 がそれぞれ $T_{c}, T_{t}$ の連続する流速べクトル $\boldsymbol{u}_{c}$ および $\boldsymbol{u}_{t}$ により代表される周期 $T$ の周期運動として表現される （図一-1(c)）と仮定する.

したがって, 無次元漂砂量ベクトル $\boldsymbol{\Phi}$ は Dibajnia・ Watanabe (1992) の式を拡張した式（3）により算定で きることになる.

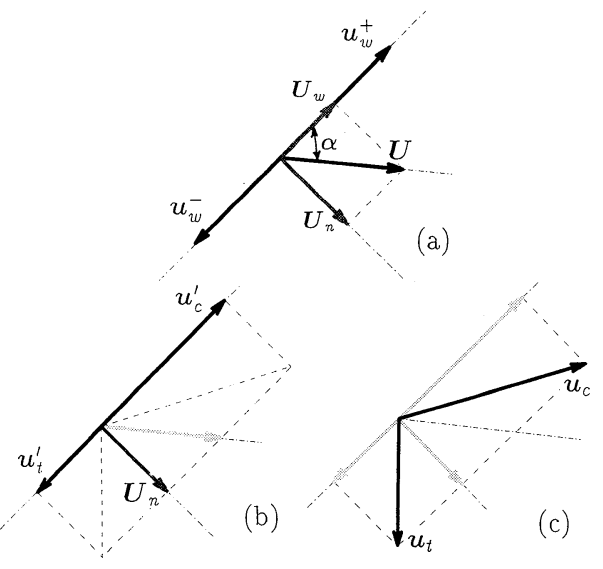

図一1 波・流れ共存場に対する各流速ベクトルの定義 


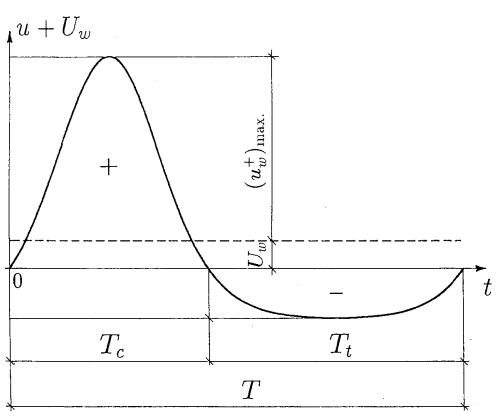

図-2 底面近傍流速の波進行方向成分の時間変化

$$
\boldsymbol{\Phi}=\frac{\boldsymbol{q}_{\text {net }}}{w_{0} d}=0.001 \cdot \frac{\Gamma}{\Gamma} \cdot \Gamma^{0.55}
$$

ここに,

$$
\boldsymbol{\Gamma}=\frac{T_{c}\left(\Omega_{c}^{3}+\Omega_{t}^{\prime 3}\right) \boldsymbol{u}_{c}+T_{t}\left(\Omega_{t}^{3}+\Omega_{c}^{\prime 3}\right) \boldsymbol{u}_{t}}{\left(u_{c}+u_{t}\right) T}
$$

$$
\left\{\begin{array}{l}
\text { if } \omega_{j} \leq \omega_{\text {critical }} \\
\left\{\begin{array}{l}
\Omega_{j}=\omega_{j} \cdot \frac{2 w_{0} T_{j}}{d} \\
\Omega_{j}^{\prime}=0
\end{array}\right. \\
\text { if } \omega_{j}>\omega_{\text {critical }}\left\{\begin{array}{l}
\Omega_{j}=\omega_{\text {critical }} \cdot \frac{2 w_{0} T_{j}}{d} \\
\Omega_{j}^{\prime}=\left(\omega_{j}-\omega_{\text {critical }}\right) \cdot \frac{2 w_{0} T_{j}}{d}
\end{array}\right.
\end{array}\right.
$$

$$
\omega_{j}=\frac{1}{2} \frac{u_{j}^{2}}{s g w_{0} T_{j}}
$$

上式で, $\boldsymbol{q}_{\text {net }}$ は単位幅・単位時間当たりのネットの漂砂量 ベクトル， $d$ は底質粒径， $w_{0}$ は沈降速度， $s=\left(\rho_{s}-\rho\right) / \rho$ ( $\rho_{s}$ と $\rho$ は水と底質の密度) であり, 添字 $j$ は $c$ または $t$ で置き換えられる。の限界值 $\omega_{\text {critical }}$ は次式で与えられ る.

$$
\begin{aligned}
& \omega_{\text {critical }}=1-0.97 \sqrt{\Lambda} \cdots \cdots \cdots \cdots \cdots \cdots \cdots \cdots \cdots \cdots \cdots \cdots \\
& \Lambda=\left\{1-\left[\left(\Psi_{\mathrm{rms}}-0.2\right) / 0.4\right]^{2}\right\} \cdot \min \left(1,2 \lambda / d_{0}\right) \cdots
\end{aligned}
$$

ここで， $\Psi_{\mathrm{rms}}$ は図-2で表された底面近傍流速の rms 值,

$$
u_{\mathrm{rms}}^{2}=\frac{2}{T} \int_{0}^{T}\left(u+U_{w}\right)^{2} \mathrm{~d} t
$$

を用いて計算されるシールズ数である．このとき摩擦係 数の算定には Jonsson (1966)の方法を用いている.さら に, 式（8）では $\lambda$ は砂漣波長， $d_{0}$ は底面近傍軌道直径 を表している. シートフロー条件に相当する $\Psi_{\mathrm{rms}}>0.6$ の場合には， $\Lambda=0.0$ とする. $\Lambda$ が 1.0 に近づくにつれ $\omega_{\text {critical }}$ は掃流漂砂に相当する値 0.03 にほぼ等しくなる.

\section{3. 拡張された漂砂量算定法の検証}

前節に示した拡張された漂砂量算定法の妥当性を検証 するために，港口部における底面高の局所的変化の計算
にそれを応用し，現地データと比較する。このデータは 1992 年 2 月に東京電力柏崎刚羽原子力発電所の取水港 湾港口部で行われた現地観測により得られたものである （清水ら，1993）。連続記録のために, $40 \mathrm{~m} \times 40 \mathrm{~m}$ の観測 域に，圧力センサーを装着した 5 台の電磁流速計と 9 台 の光電式砂面計が設置された.

観測域内の平均底面高変化の計算に際しては, 毎時 20 分平均の有義波高，有義波周期，波向および平均流の流 速と流向を用いた。底面近傍の非対称な軌道流速波形は, 磯部・堀川（1981）の方法により, 有義波高・周期から 算定した。図一 3 に計算結果と実測データが比較されて いるが，両者は良好な一致を示している，なお，実測デ 一夕に数か所認められる底面高の急激な変動は, 流れ場 の急変時に生じた砂面計による局所洗掘の影響と考えら れる。

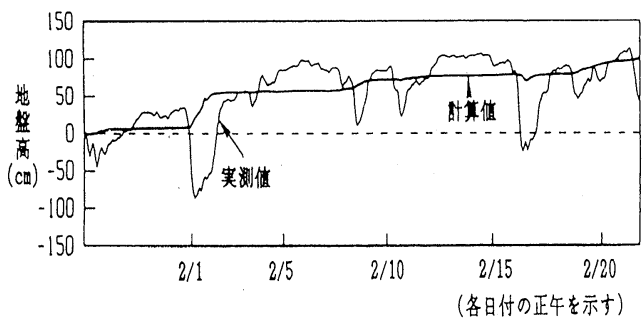

図-3 港口部底面高変化の現地観測値と計算値の比較

\section{4. 漂砂量算定法の沿岸漂砂量計算への応用}

海浜変形の長期予測計算のためには，沿岸漂砂による 地形変化のみを考えれば充分な場合が多いといわれてい る、しかしながら, 各点の漂砂量は, 波浪の変形や様々 な平均流の発生を含む複雑な 3 次元過程により支配され る.したがって, 底面近傍軌道流速の非対称性や戻り流 れなどの主に岸沖方向の現象も，各点の沿岸漂砂量およ び総沿岸漂砂量に影響するはずである。このような観点 から, 今回提示した漂砂量算定法を沿岸漂砂量の計算に 応用して上記の影響を検討することは有意義であると思 われる。

このために, 直線状平行等深線の一様勾配海浜を対象 に，広範な現地規模の条件をカバーする 160 ケースに対

表-1 沿岸漂砂量の計算条件

\begin{tabular}{c|c|c|c|c}
\hline $\begin{array}{c}d \\
(\mathrm{~mm})\end{array}$ & $\tan \beta$ & $\begin{array}{c}\theta_{0} \\
(\mathrm{deg})\end{array}$ & $\begin{array}{c}T \\
(\mathrm{~s})\end{array}$ & $\begin{array}{c}H_{0} \\
(\mathrm{~m})\end{array}$ \\
\hline & & & 6.0 & 0.3 \\
0.2 & $1 / 20$ & 15 & 8.0 & 0.6 \\
0.8 & $1 / 50$ & 45 & 10.0 & 1.0 \\
& & & 18.0 & 2.4 \\
\hline
\end{tabular}


して計算を行った。表一 1 亿計算条件を示す. 表中 $\tan \beta$ は海底勾配， $\theta_{0}, T, H_{0}$ は入射沖波の波向, 周期, 波高で ある. 沿岸漂砂は，1）規則波十沿岸流，2）規則波+ 戻り流れ+沿岸流，3）不規則波十戻り流れ+沿岸流, の 3 種の条件に対して計算された。

規則波の変形計算には, 砕波によるエネルギー減衰項 を含む波エネルギー保存式（Dibajnia・渡辺，1987）を用 い, wave setup による汀線位置の変化も考慮した. 戻り 流れは岡安ら（1989）の方法により, 沿岸流は次式（西 村，1988）により，それぞれ計算した。

$$
\begin{aligned}
& \rho C_{\mathrm{f}} \tilde{W} V_{l}-\frac{\mathrm{d}}{\mathrm{d} x}\left[\mu_{e} D \frac{\mathrm{d} V_{l}}{\mathrm{~d} x}\right]+\frac{\mathrm{d} S_{x y}}{\mathrm{~d} x}=0 \\
& \left.\begin{array}{rl}
\tilde{W}= & W+(\tilde{u} \cdot \sin \theta)^{2} / W, \quad \tilde{u}=(2 / \pi) \widehat{u}_{b} \\
W= & {\left[\sqrt{V_{l}^{2}+\tilde{u}^{2}+2 V_{l} \tilde{u} \sin \theta}\right.} \\
& \left.+\sqrt{V_{l}^{2}+\tilde{u}^{2}-2 V_{l} \tilde{u} \sin \theta}\right] / 2
\end{array}\right\} \\
& \mu_{e}=\rho N \xi \sqrt{g D}
\end{aligned}
$$

ここで, $V_{l}$ は沿岸流流速， $C_{\mathrm{f}}$ は流れに対する摩擦係数, $S_{x y}$ はラディエーション応力, $D$ は水深, $\widehat{u}_{b}$ は底面近傍 軌道流速振幅, $\mu_{e}$ は水平拡散係数, $\xi$ は平均汀線からの離 岸距離である. $N$ としては 0.01 を用い， $C_{\mathrm{f}}$ は Jonsson （1966）の方法により $\tilde{W}$ とから算定した。

不規則波の場合に，相当する規則波と等しい総エネル ギーを持つ狭帯域単一方向不規則波を仮定し, 有義沖波 の波高と周期を次式で与えた。

$$
H_{0_{1 / 3}}=\sqrt{2} H_{0}, \quad T_{1 / 3}=T
$$

不規則波の変形計算には，磯部（1986）による砕波減衰 表示式を含むエネルギー保存式を用いた。なお，本研究 で用いた不規則波に対する砕波位置の決定法は Dibajnia ら（1993）によるもので, 現地観測データともよく一 致することが確かめられている。 また, 沿岸流の計算は 規則波の場合と同様に式 (10)〜 (12) を用いて行ったが， 戻り流れは Dibajnia ら（1993）の式で計算した。底面近 傍の非対称な軌道流速の計算は, 規則波 - 不規則波とも に磯部・堀川（1981）の方法によった。

沿岸流の計算結果の精度を検討するために，図一 4 と 図一5に例示するように, Thornton・Guza (1986) の現 地データおよびVisser（1984）の規則波の下での実験デ ータとの比較を行った。その結果, 実測デー夕とのよい 一致を得るためには, 上記の方法による摩擦係数 $C_{\mathrm{f}}$ の計 算値を, 現地条件の場合は 2 で, 実験室条件の場合は 4 で割る必要があることが分かったので，今回の計算では 全ケースについて 2 で割った值を用いた。

水中重量表示の総沿岸漂砂量 $I_{l}$ は次式のように, 局所 沿岸漂砂量 $i_{l}(x)$ を岸沖方向に積分して求めた.

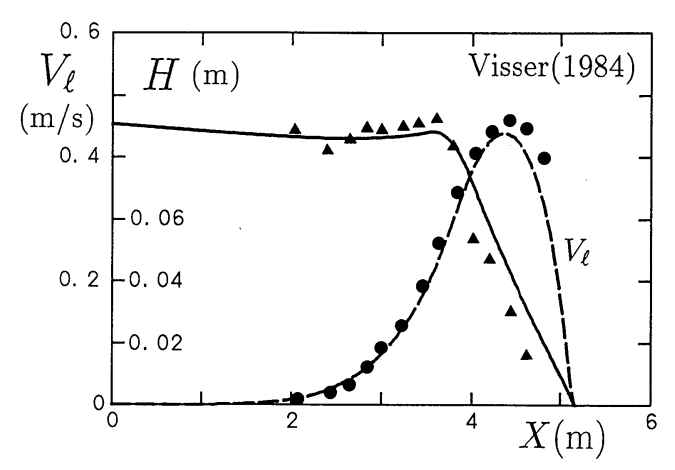

図-4 沿岸流流速分布の実測值と計算値の比較例（1）

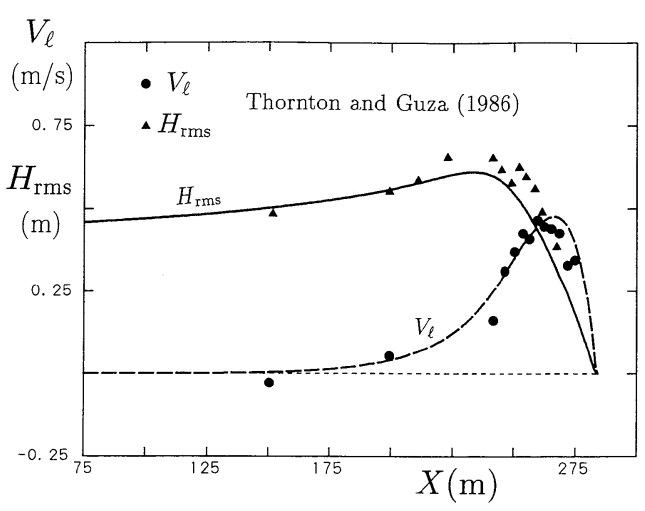

図一-5 沿岸流流速分布の実測值と計算値の比較例（2）

$$
I_{l}=\int_{x_{0}}^{x_{s}} i_{l}(x) \mathrm{d} x
$$

ただし， $x_{0}$ は砕波点より充分に沖側にとられた計算境界 点の座標, $x_{S}$ は平均汀線位置の座標である.

\section{5. 総沿岸漂砂量の計算結果と考察}

水中重量表示の総沿岸漂砂量 $I_{l}$ と次式で定義される 砕波点における波のエネルギーフラックスの沿岸方向成 分 $P_{l}$ の関係について検討する.

$$
P_{l}=E_{\mathrm{B}} C_{g \mathrm{~B}} \cdot \sin \theta_{\mathrm{B}} \cos \theta_{\mathrm{B}}
$$

ここで, $E_{\mathrm{B}}, C_{g \mathrm{~B}}, \theta_{\mathrm{B}}$ はそれぞれ砕波のエネルギー, 群速 度, 波向角である。図一6 は戻り流れを無視した場合に規 則波に対して計算された $I_{l}$ と $P_{l}$ の関係を示す.これを 詳細にみることにより, 両者の関係は波の周期 $T$ に依存 していることが分かる，すなわち，次式：

$$
I_{l}=a \cdot P_{l}^{b}
$$

の関係が成り立つものとすると, 周期の増加につれて, 上式中の比例係数 $a$ は 0.05 から 0.03 に減少し, 指数 $b$ は 1.04 から 1.21 に増加する. 周期以外の影響は, 周期が $6 \mathrm{~s}$ の場合に入射波向に対する依存性がわずかに認めら れるのみである.なお, $I_{l}$ と $P_{l}$ が比例すると仮定すると, 

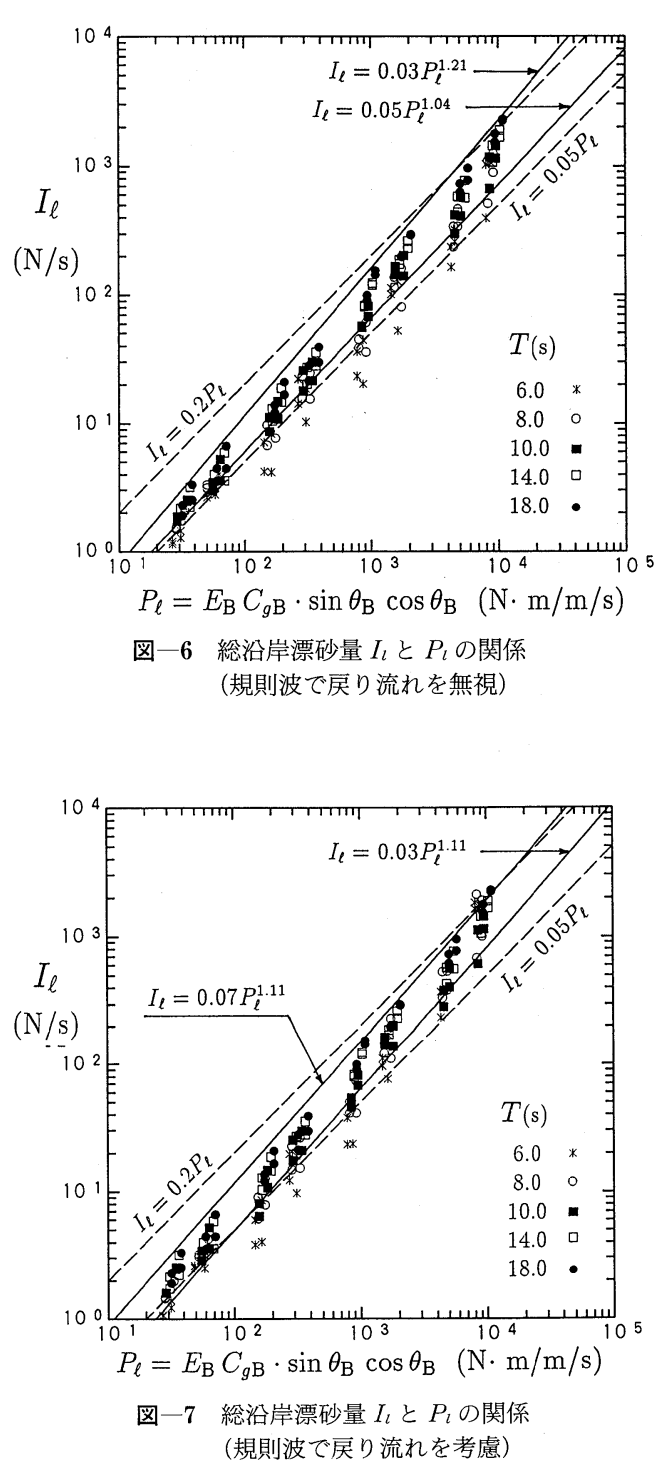

$I_{l}=(0.05 \sim 0.2) P_{l}$

が得られ, 比例係数の值は CERC 公式中の係数値 0.77 に比して極めて小さくなっている。

戻り流れを考慮した場合の規則波に対する計算結果 は, 図一7に示されている.ややり周期に対する依存性が 認められるが, この場合は周期の影響は係数 $a$ にのみ現 れ，しかも $a$ の值は周期とともに増加する. $I_{l}$ と $P_{l}$ の関 係は次式で表示できょう.

$$
I_{l}=(0.03 \sim 0.07) P_{l}^{1.11}
$$

ただし全体的にみて, 総沿岸漂砂量に対する戻り流れの 効果は余り重要でないように判断される.

图一8 は不規則波に対して戻り流れを考慮して求まっ た結果を示しており, この結果から次式が得られる.
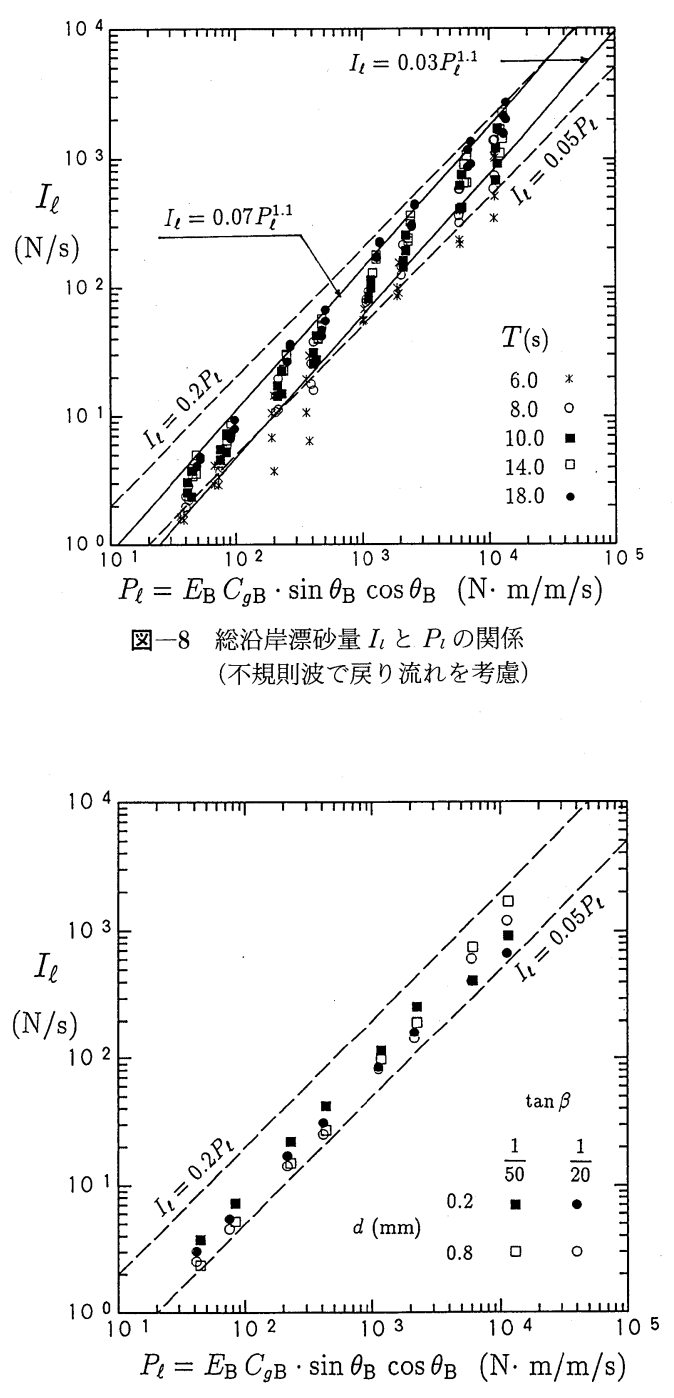

目一9 総沿岸漂砂量 $I_{l}$ と $P_{l}$ の関係 (不規則波で戻り流れを考慮， $T=10 \mathrm{~s}$ )

$I_{l}=(0.03 \sim 0.07) P_{l}^{1.10}$

この場合も $a$ の值は周期とともに増加し, 式 (18) と式 (19) は互いに極めて近い関係を与える. 線形関係を仮定 すると,

$$
I_{l}=(0.05 \sim 0.2) P_{l}
$$

となり, 係数值はやはり CERC 公式に比してかなり小さ いが, 従来の多くの研究・報告で過去の地形測量デー夕 によって1-line モデルを検定した際に求まっている関 係とは合致している.

なお，周期 $10 \mathrm{~s}$ の波について得られた結果だけを別に 図一9に示した.この図から, 戻り流れの存在する不規則 波浪場では，波高（エネルギー）が増加するにしたがっ て底質の粒径の違いや底面勾配の影響が明らかになり, 

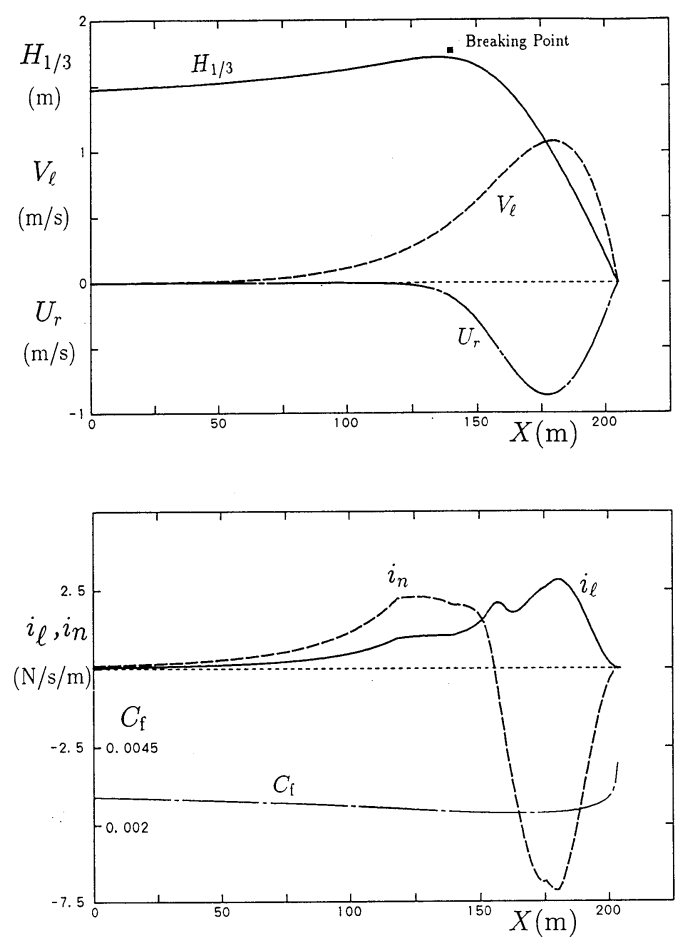

図-10 各変量の岸沖分布の 1 例

相対的な散らばりが明確になっていくことが分かる.

最後に図一 10 に, 不規則波に対する計算結果の 1 例と して, $d=0.2 \mathrm{~mm}, \tan \beta=1 / 20, \theta_{0}=45^{\circ}, T_{1 / 3}=10.0 \mathrm{~s}$, $H_{0_{1 / 3}}=1.7 \mathrm{~m}$ の場合について, 有義波高 $H_{1 / 3}$, 沿岸流流速 $V_{l}$, 戻り流れ流速 $U_{r}$, 漂砂量の岸沖成分 $i_{n}$, 沿岸成分 $i_{l}$, ならびに摩擦係数 $C_{\mathrm{f}}$ の岸沖分布を示す.前述のように総 沿岸漂砂量は戻り流れを考慮しても余り変化しないこと が示されたが，図一10における沿岸漂砂量の岸沖分布 は, 确波点の近くで最大值をとるという従来の多くの理 論的モデルとかなり異なっており，この相違には戻り流 れの存在が影響していることが分かる。 なお, 摩擦係数 $C_{\mathrm{f}}$ の平均值は約 0.003 である.

\section{6. 結 語}

Dibajnia・Watanabe (1992) による漂砂量算定式を, 波と流れが任意角度で交差する場合に拡張した，波・流 れ共存場における局所漂砂量の予測に対するこの一般化 された算定式の適用性は, 現地観測データとの比較によ り検証された. 更にこの式を応用して, 沿岸漂砂の総量 と岸沖分布ならびにそれらに対する波と流れの影響を検 討した. その結果, 戻り流れは総沿岸漂砂量には余り影 響しないが, 沿岸漂砂量の岸沖分布に対する影響は無視
できないことが分かった。

算定された総沿岸漂砂量 $I_{l}$ と砕波エネルギーフラッ クスの沿岸方向成分 $P_{l}$ はかなり高い相関を示した.ただ し両者の関係は，比例関係からは若干はずれ，また波の 周期に対するかなりの依存性が認められた。しかしなが ら, 波打ち帯およびその近傍で極めて活発な底質移動が 存在することを示したいくつかの報告(例えば, White・ Inman, 1989）があるにもかかわらず，本研究も含め従来 のほとんど全ての理論モデルにおいては, 静的な汀線を 考えてそこでの流速が 0 になるというかなり非現実的な 仮定を行っていることに，充分に留意しておく必要があ る。すなわち，波打ち帯のいわゆる浜漂砂の合理的な評 価を取り込むことにより，本算定式の一層の改良が期待 される.

\section{参 考 文 献}

磯部雅彦 (1986)：放物型方程式を用いた不規則波の屈折・回折・ 砕波変形の計算法, 第 33 回海岸工学講演会論文集, pp. 134138.

磯部雅彦・堀川清司（1981）：砕波帯付近における流速場の浅水 変化化関する研究, 第 28 回海岸工学講演会論文集, pp. 5-9.

岡安章夫・磯部雅彦・渡辺 晃 (1989): 研波帯におけるエネル ギー収支と戻り流机のモデリング, 海岸工学論文集, 第 36 巻, pp. 31-35.

清水环三・水流正人・嶋田昌義・䆶 泰浩・山田富朗（1993)：取 水港湾港口部の長期的な地形変化の再現, 海岸工学論文集, 第 40 巻, pp. 496-500.

西村仁嗣 (1983)：流れの場の計算, 堀川清司 (編), 海岸環境工 学, 第 3 編, 第 3 章, 東京大学出版会, pp. 249-252.

Dibajnia, M. 渡辺 晃 (1987): 波浪場と海浜縦断地形変化の数 值計算モデル, 第 31 回海岸工学講演会論文集, pp. 324-328.

Dibajnia, M. 清水琢三・渡辺 晃 (1992)：シートフロー状態が 卓越する海岸にっける䋛断面地形変化の数值計算, 海岸工学 論文集, 第 39 巻, pp. 301-305.

Dibajnia, M. 清水琢三・渡辺 晃 (1993)：現地海岸に打ける縦 断地形変化の再現, 海岸工学論文集, 第 40 巻, pp. 406-410.

Dibajnia, M. and A. Watanabe (1992): Sheet flow under nonlinear waves and currents, Proc. 23rd Int. Conf. on Coastal Eng., pp. 2015-2028.

Dibajnia, M., T. Shimizu and A. Watanabe (1994): Profile change of a sheet flow dominated beach, Proc. 24th Int. Conf. on Coastal Eng. (to be presented)

Jonsson, I. G. (1966): Wave boundary layers and friction factors, Proc. 10th Int. Conf. on Coastal Eng., pp. 127-148.

Thornton, E. B. and R. T. Guza (1986): Surf zone longshore currents and random waves: J. Phys. Oceanography, Vol. 16, pp. 165-1178.

Visser, P. J. (1984): Uniform longshore current measurements and calculations, Proc. 19th Int. Conf. on Coastal Eng., pp. 2192-2207.

White, T. E. and D. L. Inman (1989): Measuring longshore transport with trackers, R. J. Seymour (ed.) : Nearshore Sediment Transport, Plenum Pub. Co., Chapt. 13, pp. 287312 . 